\title{
Religional Source and Politics: A Case Study on The Hadith of "Loving The Arabs is Faith and Hating Them is Infidel" and It's Relevance in Indonesia Context
}

\author{
$1^{\text {st }}$ Rizkiyatul Imtyas ${ }^{1}, 2^{\text {nd }}$ Kusmana $^{2}, 3^{\text {rd }}$ Alvin Noor Sahab Rizal ${ }^{1}, 4^{\text {th }}$ Didin Saepudin $^{1}$ \\ \{rizqyatulimtyaz1996@gmail.com¹,kusmana@uinjkt.ac.id², \\ alvin.noor18@mhs.uinjkt.ac.id ${ }^{1}$ \} \\ UIN Syarif Hidayatullah, Islamic Studies Department, Jakarta, Indonesia ${ }^{1}$, UIN Syarif \\ Hidayatullah, Faculty of Ushuluddin, Jakarta, Indonesia ${ }^{2}$
}

\begin{abstract}
This study tries to analyze the hadith حب العر $\square$ إيمان وبغضهم كفر which means that loving Arabs is faith and hating them is considered infidels. This phenomenon is not spared from the politicization of hadith carried out by certain groups for their interests. Because after the death of the Prophet (s), the Muslims needed something that could replace the religious authority became the norm in daily life carried out by the Prophet (s) when he was alive. However, due to the lack of management to select hadiths in the second century Hijriyah, it is no wonder that many narrative that are spread among the people are used by certain groups for their political interests. I analyze it with the Mahmud At-Thahan's method, the conclusion is it can be concluded a weak hadith. According to the hadith scholars it cannot be used as evidence and not to be practiced.
\end{abstract}

Keywords: Hadith, Arab, Politicization.

\section{Introduction}

Islam as a symbol of an agent of peace for the whole world. which is one of the important tasks that is always applied is to uphold equality among the people without knowing the caste system and social level, because in reality, all are equal in the sight of God, but the difference is the piety of each individual itself. It was proven by the sending of Rasulullah (s) to abolish the system of slavery that was rife in the realm of ancient peoples throughout the world, this was done gradually until finally the slavery system was completely abolished throughout the world. In some narrations it is also mentioned that the Prophet (s) is the messenger of God sent to all mankind, regardless of race, race, and nation. Even the Qur'an itself states that Islam encourages its people to know and understand each other even though they come from different backgrounds to create a noble goal of tightening brotherhood without division among humans themselves, because once again what distinguishes humans in the Almighty is the piety of the individual. But there are narrated traditions; "حب العره إيمان وبغضهم كفر narrated by Al-Hâkim Al-Naisabûri in the book Al-mustadrak 'ala al-sahîhāini. In the narrative as if only the Arabs who have the authority to love, and hate them mean infidels. This gives the 
impression that Islam is a racist religion, because in reality there are also many adherents of Islam in the world, with various tribes and countries. So how is the correct understanding of this hadith? Is it true if we interpret it textually? And is it true that Islam is a religion that upholds racism? And is it true that loving the Arabs is a must that affects one's faith and disbelief? For this reason, the researcher will analyze the hadith and how the correct understanding is in accordance with the opinion from the ulama of hadith sciences who have authority in this field. Also to research the phenomena behind the contextual of this hadith. Then the researcher will also relate it to the context of Arab in Indonesia, in the sense of how the response of the Indonesian Muslim to the Arabs living side by side with them.

After seeing the theme of the thesis above, the data obtained is in the form of documents, either books or historical records, so this research belongs to the type of library research.

\section{Research Methodology}

The techniques and steps taken to analyze are as follows:

a. Collecting data through library research related to the topic to be discussed, based on primary sources; 1) al-kutub al-tis'ah 2) books of hadith 3) books of al-sharah alhadith. The secondary sources; 1) the books of aqîdah 2) the books of qur'anic and hadith exegesis 3 ) the books of history and biography 4) the books of al-jarh wa al$t^{\prime}$ 'dîl and others 5) the books, articles and journals related to the research topic.

b. Analyzing the hadith by using the method of al-takhrîj al-hadith by Mahmud Tahân, namely; identify the source of the hadith and its chain of sanad, and opinions of hadith scholars. Also analyzing the quality of the hadith. The steps taken in the method of takhrij are as follows; 1) looking for hadiths in the sources /books of the hadith by using themes related to the hadith, 2) or by searching for the name of the friend who narrated the hadith, 3) or by searching for the narration of the hadith as a keyword to find the hadith sought. 4) Or by using electronic devices such as "almaktabah al-shamîlah".

c. Analyzing the understanding of hadith or al-fiqh al-hadith in by following the arguments of the scholars who have authority on the topic, also based on the literature of the books of hadith, aqîdah, qur'an exegsis and fiqh.

d. Historical analysis to the background of the narration of this hadith by using contextual historical analysis.

e. Describe the phenomenon of racism and how the attitude of Indonesian people, especially Muslims, towards Arabs who live side by side in their midst. 


\section{Research Findings}

After I searched the hadith in his literatute, I found the hadith in many sources with several different lafaz, and different series of narrators as well as the following table:

Table 1. The source of the hadith

\begin{tabular}{|c|c|c|c|}
\hline Text of Hadith & $\begin{array}{l}\text { The source of the } \\
\text { book }\end{array}$ & Name of Narrators & $\begin{array}{l}\text { The owner } \\
\text { of the book }\end{array}$ \\
\hline 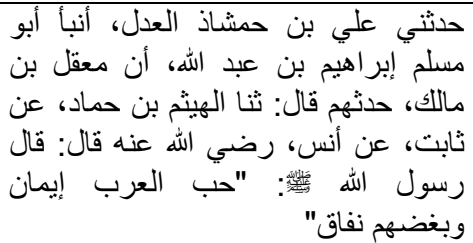 & $\begin{array}{l}\text { Al-mustadrak 'ala } \\
\text { al-șahîhâini[1] }\end{array}$ & $\begin{array}{l}\text { Anas bin Malik } \\
(93 \mathrm{H})\end{array}$ & $\begin{array}{l}\text { Al-Hakim } \\
\text { Al- } \\
\text { Naisaburi } \\
(405 \mathrm{H})\end{array}$ \\
\hline 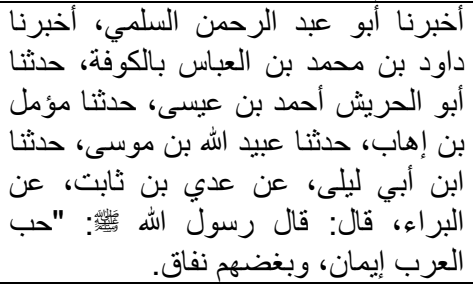 & Syu'ab al-îmân[2] & $\begin{array}{l}\text { Al-Bara' bin 'Azib } \\
\text { Al-Anshari }(72 \mathrm{H})\end{array}$ & $\begin{array}{l}\text { Al-Baihaqi } \\
(458 \mathrm{H})\end{array}$ \\
\hline 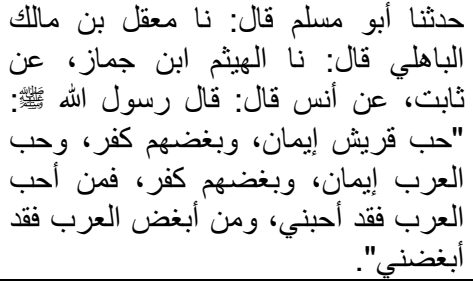 & $\begin{array}{l}A l-M u ’ j a m \\
A w s a ̂ t \underline{t}[3]\end{array}$ & $\begin{array}{l}\text { Anas bin Malik } \\
(93 \mathrm{H})\end{array}$ & $\begin{array}{l}\text { Abu Qasim } \\
\text { Al- } \\
\text { Thabrani } \\
(360 \mathrm{H})\end{array}$ \\
\hline 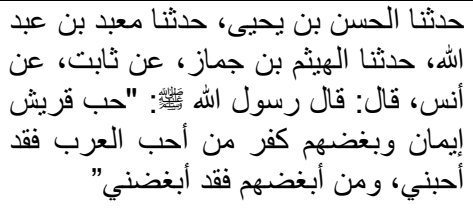 & $\begin{array}{l}A l-B a \underline{h} r \\
\text { Zakhâr }[4]\end{array}$ & $\begin{array}{l}\text { Anas bin Malik } \\
(93 \mathrm{H})\end{array}$ & $\begin{array}{l}\text { Al-Bazar } \\
(292 \mathrm{H})\end{array}$ \\
\hline 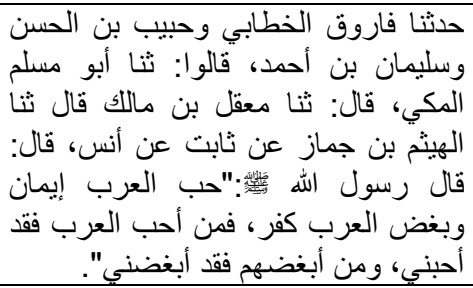 & $\begin{array}{l}\text { Hilyah } \\
\text { 'Auliya'[5] }\end{array}$ & $\begin{array}{l}\text { Anas bin Malik } \\
(93 \mathrm{H})\end{array}$ & $\begin{array}{l}\text { Al- } \\
\text { Ashfahani } \\
(430 \mathrm{H})\end{array}$ \\
\hline
\end{tabular}




\begin{tabular}{|c|c|c|c|}
\hline Text of Hadith & $\begin{array}{l}\text { The source of the } \\
\text { book }\end{array}$ & Name of Narrators & $\begin{array}{l}\text { The owner } \\
\text { of the book }\end{array}$ \\
\hline 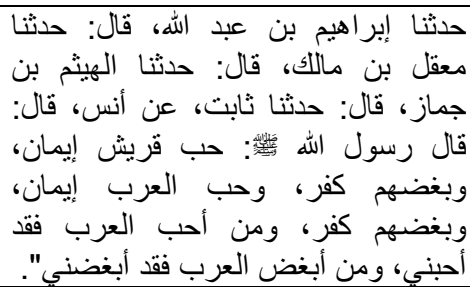 & $\begin{array}{l}\text { Al-Dhu'afấ' } A l- \\
\text { Kabîr[6] }\end{array}$ & $\begin{array}{l}\text { Anas bin } \quad \text { Malik } \\
(93 \mathrm{H})\end{array}$ & $\begin{array}{l}\text { Al-'Uqaili } \\
(366 \mathrm{H})\end{array}$ \\
\hline
\end{tabular}

\section{Discussion}

\subsection{Sanad Hadith Analysis (al-Naqd al-Sanad)}

After researching on the hadith using the method of al-takhrij al-hadith by Mahmud Thahan, I can conclude a systematic explanation as follows:

Table II

The Status of The Hadith

\begin{tabular}{|c|c|c|c|}
\hline $\begin{array}{l}\text { Riwayah } \\
\text { Resources }\end{array}$ & Status of Hadith & Cause & $\begin{array}{l}\text { Sanad } \\
\text { Status }\end{array}$ \\
\hline $\begin{array}{l}\text { Al-Hakim } \quad \text { Al- } \\
\text { Naisaburi }\end{array}$ & Dha'if Syadid & $\begin{array}{l}\text { Al-Haitsam bin Jamâz is a } \\
\text { "munkar al-hadis } \text { " }\end{array}$ & Continued \\
\hline Al-'Uqaili & Dha'if Syadid & $\begin{array}{l}\text { Al-Haitsam bin Jamâz is a } \\
\text { “munkar al-hadîs" }\end{array}$ & Continued \\
\hline Al-Thabrani & Dha'if Syadid & $\begin{array}{l}\text { Al-Haitsam bin Jamâz is a } \\
\text { "munkar al-hadîs" }\end{array}$ & Continued \\
\hline Al-Bazar & Dha'if Syadid & $\begin{array}{l}\text { Al-Haitsam bin Jamâz is a } \\
\text { "munkar } \boldsymbol{a l - h a d i s} \text { " }\end{array}$ & Continued \\
\hline Al-Ashfahani & Dha'if Syadid & $\begin{array}{l}\text { Al-Haitsam bin Jamâz is a } \\
\text { "munkar al-hadîs" }\end{array}$ & Continued \\
\hline Al-Baihaqi & Hadis Hasan & $\begin{array}{l}\text { 1) Ibnu Abi Laila dan al- } \\
\text { Mu'ammal bin Ihâb are } \\
\text { "shodîq" } \\
\text { 2)Ahmad bin 'Isa al-Kilabi is a } \\
\text { "maqbul" }\end{array}$ & Continued \\
\hline
\end{tabular}

After all the riwayah and the hadiths are collected, it can be concluded that the law of this hadith is "da'tif shadîd". So its status cannot rise and occupy the position of hasan lighairihi, because; 1) five of the six narrations of this hadith are $\underline{d} a$ 'if shadîd except al-Baihaqi, 2) although al-Baihaqi's history is considered hasan lighairihi but cannot help the five previous narrations, 3) because the reason is considered dha' $\hat{f}$ is that there is an munkar al-hadis namely al-Haitham bin Jamaz.[7] 
As for the quantity of this hadith, it can be judged that the status of this hadith is mutawattir, because; 1) five of these six narrations are only narrated through the one line Anas bin malik, Thabit al-Bunani, Haitsam bin Jamaz and Ma'qol bin Malik. 2) while from the history of al-Bayhaqi also follows one route in all of its sanad series.

The law of practicing this hadith is that it cannot be made a legal istinbath nor is it practiced because the existence of this hadith belongs to the category of dha'if shadîd which means "very dha'if". [8]

After researching, it is clear that the law of the Arabic tradition of "Hubb Arab Imân wa bugduhum kufrun" is a hadith even included in the category of "shadild", according to the hadith experts such as Mahmud Thahan in taysîr mustalah al-hadith that the dha'îf shadîd category affects the inadequacy of the hadith as a foundation law.[9]

\subsection{Matan Hadith Analysis (al-Naqd al-Matn)}

In addition to the hadith that I am analyzing, there are also several explanations from other narrations in one theme, such as the following:

a. The narration of the hadith text carried by al-Ahmad:[10]

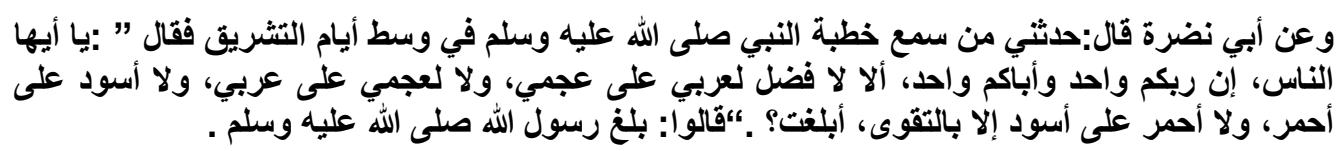

This hadis is valid as described in the book of al-Majma' al-Zawâid by al-Haitami. He said the narrator is valid.[11] Sheikh al-Albani, also said that the narration above is valid.[12]

The history above clearly states that there is no human advantage over other humans based on ethnicity and skin color. The words of the Prophet (s) by following the message of the Qur'an: "The noblest in the sight of Allah are those who fear" (Surah al-Hujurat: 13). The Prophet (s) emphasized: "There is no virtue of the Arabs over non-Arabs." What a message the Messenger of Allah was at the end of his life.

b. The narration of the hadith text carried by al-Tirmidzi:[13]

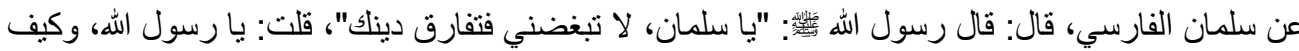

$$
\begin{aligned}
& \text { أبغضك وقد هدانا الله بك؟ قال: "تبغض فال "تبول العرب فتبغضني". }
\end{aligned}
$$

Imam Tirmidzi gave an important note: This hadith is a gharib "when it is narrated by just a single person at one point in the chain of transmittershadith". He also said "we do not know it except the hadith of Abu Badr Syuja 'bin al Walid. And I heard Muhammad bin Isma'il (Imam Bukhari) say; Abu Dhabyan never met Salman, because Salman died before Ali (died)".

It is important for us to read Imam Tirmidzi's notes above because if this hadith is understood textually as if to say we make Arabs angry, where the Prophet was angry and our aqidah could be separated. This is not in accordance with the Qur'an, other more authentic traditions, and Islamic teachings. In the science of criticism matan hadith if a history contradicts the two elements above, the narration is rejected.

Besides that, the hadith of gharîb (foreign/aloof) in the terminology of Sunan at-Tirmidzi means similar to the al-hadith al-dha'îf.

c. The narration of the hadith text carried by al-Tirmidzi:[14]

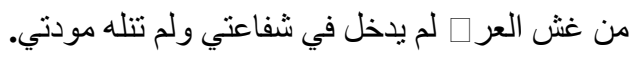


The meaning of the hadith: "Whoever deceives the Arabs, then he will not enter (from the group who will) get my shaykh, and not get my love."

In terms of the meaning contained in the editions of hadith also have meaning that contradicts the Qur'an, the traditions in other narrations are more valid and the core of Islamic teachings.

Imam at-Tirmidzi said; "This hadith is the gharîb hadith, we don't know it except the hadith of Hushain bin Umar al-Ahmasi from Mukhariq and according to the hadith expert, Hushain's history is not strong." It can be concluded that this hadith was also considered a dha'îf (weak).

So it is clear that the hadith which says there is no Arab superiority over other nations is valid. While the history of the virtues of the Arabs we should question but make no mistake. We also cannot insult Arabs. Arabic is the language of the Qur'an. The Arabic line was noble to the birth of the Prophet Muhammad (s). The Prophet (s) loved the city of Mecca. Prophet Muhammad (s) is also an Arab. It is impossible for us to hate Arab nations and traditions.

On the other hand, some of the hadiths explain the glory of non-Arabs or also referred to as 'ajam. This proves that the Holy Prophet also glorified non-Arabs, and in general did not differentiate the people according to the category from which he came. As for some of the hadiths that explain the virtues of non-Arabs are as follows;

a. Riwayah al-Tirmidzi

عن أبي هريرة، يقول: ذُكرت الأعاجم عند النبي صلى الله عليه وسلم، فقال النبي هَبَّة: "لأنَا بهم أو ببعضهم أوثقُ مني بكم أو ببعضكم.

On the authority of Abu Hurairah, he says: The dictionaries (non-Arabic) were mentioned by the Prophet, may God's prayers and peace be upon him, and the Prophet said: "Because I am with them or some of them".

b. Riwayah al-Tirmidzi

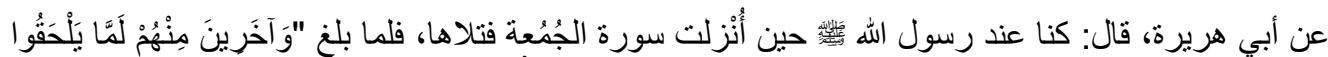

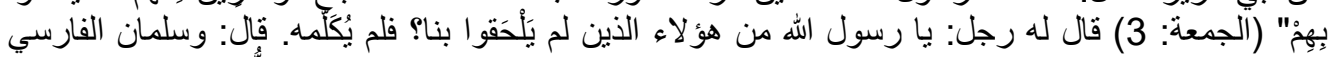

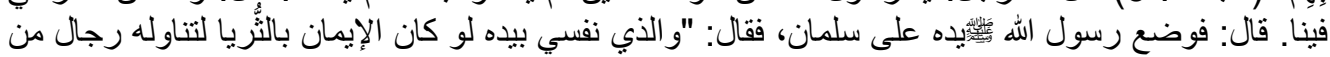

$$
\begin{aligned}
& \text { هؤلاء. }
\end{aligned}
$$

On the authority of Abu Hurairah, he said: We were with the Messenger of God (s) when Surah Al-Jumu'ah was revealed and read it, and when he reached "and others from them, when they did not catch up with them" (al-Jumu'ah: 3) A man said to him: O Messenger of God, who are those who did not follow us? He did not speak to him. He said: And Salman Al-Farsi is in us. He said: So the Messenger of God placed his hand on Salman, and he said: "And whoever is in my hand would have had faith in the chandeliers to have been eaten by men of these.

\section{Who is Arab?}

Question; "Who is Arab?" it is a difficult question that is easy to answer. At least there are several aspects that need to be considered to obtain this answer satisfactorily. First, genealogically. Arabs are seen as a race that refers to the scale of territory.

We can use Philip K. Hitti's teory in the History of Arabs to divide Arabia geographically and race in the era before the arrival of Islam. The separation which divides into two general criteria. First the South Arabs, and second, the North Arabs. 
South Arabs refer to more developed regions. Around Yemen, Hadramaut, and along its coast, people do not use Arabic, but Old Semitic languages. It was these South Arabs who then had international relations until at least the 5th or 6th century AD. The Greeks called it "Arabia Felix" which means the lucky Arab region.

Compared to South Arabs, North Arabs are a little behind. They were in the harshness of the hostile geographical conditions - the vast ocean of the desert - most of the North Arabs were still nomadic (even today), although some lived in Hijaz and Nejed. The language used in these areas is Arabic.

The North Arabs have only developed written literacy since the arrival of the Prophet Muhammad. Before that, the culture of North Arab literacy was more inclined to oral literacy. Prose, poetry, poetry, to Arabic proverbs with beautiful rhyme and diction for generations through memories that are conveyed by word of mouth. Therefore, the term "jahiliyah" is more closely related to the North Arabs.

It is at this stage that the second aspect of obtaining the limits of "who is Arabic?" Appears. Aspects of language. The Arabic term is used for areas that use Arabic as their "mother tongue". At this point, the debate arises whether Egypt and countries throughout North Africa, including "Arabic", because practically Arabic is not the mother tongue of these nations.

We also need to know what is meant by "Arabic" and "Arabian Peninsula." The peninsula, which means land that runs into the sea as if it were an island, is a fairly clear geographical boundary. designation to mark the geographical region of the desert peninsula. The boundaries are the Red Sea and the Gulf of Aqabah in the southwest, the Arabian Sea in the southeast, and the Gulf of Oman and the Persian Gulf in the northeast, Yemen, Oman, United Arab Emirates, Qatar, and Bahrain. [15]

William Montgomery Watt, professor of Arabic and Islamic studies at the University of Edinburgh, in his essay "Who is an Arabic?" mentioned that the presence of Muhammad with Islam did not only bring about a change in the beliefs of the North Arabs but also of the Arabs as a broad political entity. From the appearance of the first revelation until his death, the hostile tribes that spanned one another so quickly were united in one equation: Islam.

This is where the third aspect arises: the political aspect. The expansion of the influence of Islam from the Caliphate of Umar bin Khattab to the era of the Bani Abassiyah soon expanded the term "Who is Arab?". Expansion of territory that continued until 750 AD. The term "Arabic" then stretches from Spain (Andalusia) to Central Asia (Punjab). At the same time disseminating Arabic and Islamic religions which became the terminology of who is called Arabic.

Even though it is identical to Islam, Arabic culture was originally a picture of the beliefs of the Semitic heritage. In that era, awareness of the existence of a single God had emerged. Only, then came the new "gods" in the form of al-zza Uzza, Al-Lat, and Manat, who were considered three daughters of God.

These three new "gods" had a place of worship near the city of Mecca, where the ancestors of the Arabs - Ibrahim and Ismail - founded the Kaaba. This shows that the Arab Nation has a variety of religions, both from before the arrival of Islam to the modern era. From Christians, Jews, Magi, to paganism. Although Islam - of course - is a very dominant religion.

In the end, those three aspects are the answers of each determinant used. If we mention the Arabian Peninsula, then we will talk on geographical boundaries. If we call "the Arab world", then we will use the lens of language. All Arabic-speaking communities including the Arab world: from Algeria to Egypt in North Africa, to all countries in the Arabian Peninsula. 
This was then the reason Iran and Turkey did not belong to the "Arab World." Both in the history of civilization and in language, they were different from Arabic. Iran with Persia and Turkey with 'Roman' (also called Eastern Rome) make the inheritance of the languages used also different: Farsi and Turkish.

It is different again to say "Islamic State." The main reference is, of course, the area in the Arabian Peninsula, especially Saudi Arabia because the territory and historical sources originally originated there. This title also refers to the state system which still uses Islamic religious laws.[16]

Interestingly, when referring to "Muslim countries", according to the American-Arab Anti Discrimination Committee, it is actually Indonesia who gets the title. Of course, because adherents of Islam, aka Muslims in Indonesia, reach 170 million people. The biggest in the world.[17]

\section{Arab is Better than Non-Arab?}

This is a very important problem because there is a lot of confusion. Hadith which has meaning about the virtues of the Arabs is something important to understand. But if understood more in-depth, the purpose of the Arabic glory in these traditions is individual and not universal Arabic. Likened, for example in a school there are two classes: The first and the second grade. The first class is a collection of students between the ages of seven to eight years. And in the second grade by students who are older than first-year students, and academically it can be said that second-grade students are superior in understanding the material because they have mastered the first-grade material. Therefore, it is natural that the teacher might be more proud of second-grade students who are superior to one level than first grade, and this is natural, where is the problem?

Like the Arabs, it cannot be denied that the services of the Arabs to the Islamic civilization were also numerous, and to this day, the proportion of scholars, scientists, and Mujahidin is greater than the others. A Muslim cannot fully understand the Qur'an and the Hadith without proficiency in Arabic.

But it needs to be emphasized, the context of loving or glorifying here must be in accordance with its portion. If Arabs make a mistake then they must be punished according to applicable regulations. In society, especially in a pluralistic region of culture, ethnicity, and religion, a tolerant and fair attitude is certainly necessary to achieve mutual benefit.

Shaykh al-Islam Ibn Taymiyyah said in his book al-iqtidha 'al-sirat al-mustaqim: "ethnic Arabs are better than non-Arab ethnicities (Hebrew and Syriac, Roman and Persian and others), and that the Quraysh of the Arabs the best and the Bani Hashim Quraish and that the Messenger of Allah saw the best Bani Hashim. This is the best of creation and the best proportion ". He also explained that this hadith does not mention the following series of words: the Arabs are the noblest, then only the Quraysh, then Bani Hasyim, then Prophet Muhammad (s). this is due to the context of "services" that make each person glorified and to glorify the Prophet who came from Arabic. Besides that, in fact, many of the enemies of the Prophet who were guilty of Arabic and even the Quraysh, like Abu jahal and Abu lahab.[18]

\section{The Urgency of "Arab" in The Hadith "Hubb al-Arab Îmân"}

As mentioned by Ibn Taymiyyah, what is meant by glorifying the Arabs here is specifically because of the presence of the Prophet who came from his nation.

But in the science of aqidah, the context of "Arab love and hatred" is categorized in the "branch of faith", which in "priests" has 70 branches. 
The most important faith is worshiping Allah and the lowest branch of faith is getting rid of the thorn in the road. For the law of "hating Arabs" in the context of monotheism, it is considered nifaq because it hates it the same as it hates the Prophet (s), although other narratives have a "kafir" term for their prisoners, it does not lead to the exit of a person from Islam.[19]

In addition, the traditions that show nifaq or disbelief for those who hate Arabic are the hadith traditions that are $d a^{\prime} \hat{\imath} f$ (weak) and cannot be used as evidence in Islam.

\section{There is Shi'ah Rawi in Hadith}

'Adi ibn Thabit Al-Kufi (116 H) and' Ubaydullah ibn Musa Al-bAbasi Al-Kufi (213 H) both of whom also lived in the second century Hijriyah. This is evidenced by the justification of the ulema jarh wa al-ta'dil, who has the authority to choose narrators according to the agreed-upon hadith scientific standards, including al-Dzahabi $(748 \mathrm{H})$, Ahmad bin Hanbal $(241 \mathrm{H})$, Abu Hatim al-Razi $(277 \mathrm{H})$, al-Daruquthni $(385 \mathrm{H})$, Yahya bin Ma'in $(233 \mathrm{H})$, Abu Dawud $(275 \mathrm{H})$ and others.[20]

This is also reinforced by the claim of the Shi'ah group "The Indonesian Ahlu Bait Team" in the "Shi'ah School White Book: According to Ulama that have the authority" which explains that 'Adi bin Thabit and' Ubaidullah bin Musa are Shi'ah narrators.[21]

\section{What's Wrong with The Second Century of Hijriyah?}

\subsection{In the hadith historiography}

Because of the status of Huthaim bin Jammaz, which is considered contradictory in the narration of the hadith, and he has a background in life in the second century Hijriyah, an important question arises: What keeps Hutsaim bin Jammaz's hadith history circulating?

Ibn Hajar in his work "tadrîb al-râwi" explains that in the second century the hijriyah arose the will of the narrators of the hadith to collect and record as many traditions as possible, without considering to critically examine more deeply. Until it is mixed with a valid hadith from the Prophet Muhammad (s), and fatwas - shahabah and ulama's words and tabî'în. Furthermore, they have not clarified the contents of the Hadith texts according to their classification.

Thus, there is a fact that the hadith were written by second-century Hijri scholars still mixes with the traditions of the Prophet and the fatwas of the Companions and Tab'iin. And there are still many books of hadith written by scholars at this time there is no boundary between the hadith marfu ', mauqûf and maqtû'. Then between the authentic hadith, hasan and da'îf.

The books of hadith scholars in this era are: al-Muwata' by Imam Malik $(179 \mathrm{H})$, alMusnad Abi Hanifah al-Nu'mân $(150 \mathrm{H})$, al-Musannaf by Sufyan bin' Uyaina $(175 \mathrm{H})$ and so on.

While the hadith selection process was only carried out in the third century Hijriyah together with the emergence of thematic hadith books by scholars such as al-Bukhari $(256 \mathrm{H})$, Muslim imams (261 H) and so on.[22]

\subsection{Political and ideological dynamics}

Al-Tabari in his book mentioned that in the second century Hijriyah was the year when the political conflict began to grow with the presence of several sects and groups in Islam which were based on theology, politics, and ideology. This is also due to the fact that the 
Islamic territory is increasingly spread on the Arabian peninsula, even further. The groups in question are Muktazilah, Syi'ah and Khawarij.

Not only that, the figure of the Prophet as a mediator who brought the arguments - the proposition was gone, all that remained was the writings of his traditions which because at that time the hadith had not been selected and mixed with the others. So it did not rule out the traditions that hadith not from prophets and the refinement of traditions used as a basis for strengthening irresponsible political factions.[23]

\subsection{Historical Facts about The Hadith Politicization}

The Arabs are a nation known for having great memorization skills and oral traditions. Therefore, not many Arabs can write. those who could write were few, even those who were good at writing at that time were people who had correspondence interests such as the regional head and so on. And stated also in Mecca, only 17 people can write, in the sense of writing and correct. Writing is extraordinary and is a symbol of the perfection of someone at that time. This can be seen from the Arabic words, "a person is complete when he is able to shoot, climb and write".[24]

The hadith that we received and received today is from the Messenger of Allah. Because in its history, hadiths were not collected when the Prophet was still alive, even the Prophet never wrote the hadith because the text of the Qur'an and the hadith would not be mixed at that time. Also, during the Caliph Abu Bakr, it still tightened the hadith written because not all people were strong in memorizing and were good at writing during Abu Bakr. But some people write hadith texts, such as Ibn Abbas and other friends who meet the criteria for requesting the hadith.

Then during Umar bin Khattab's leadership, official bookkeeping activities began. He asked for a friend's opinion and asked to record it. However, after Umar performed istikharah for a long time, he canceled the plan, because it was still focused on preserving the Qur'anic text first. During the Caliph Uthman, the Koran was forgiven.

During Ali's leadership, the hadith had begun to form, the fabrication of the hadith was more widespread, even the hadith was used as a tool to support certain opinions or interests in accordance with the interests of a group. It Cannot be separated from the ideal leadership transmission. What changed had to be the Prophet's messenger, but instead became a tool for group politicization to show his existence at that time. To talk about groups and support one another, false traditions are used. While those who make traditions such as favor Quraysh more than others in terms of leadership, a Muslim but someone who will rule.[25]

Further review of the hadith was actually codified or compiled into a suhuf and then recorded beginning at the time of the Umayyad dynasty which was spearheaded by Caliph Umar bin Abdul Aziz. Abd al Aziz bin Marwan organized a governor in Egypt, but this opinion is less strong and more said that the hadith was spearheaded by Umar Abd al Aziz. This was done because it was considered several false traditions and denied that they were the first source of Islamic law.

There was a vulnerable period time from the time of the Prophet to Umar bin Abdul Aziz from the Umayyad dynasty. Wich allows the mixing of true and authentic hadith mixed with politicization to support one group or interest. This cannot be denied because there is no evidence to suggest that the hadith is truly authentic from the messenger of Allah. This is evidenced by the absence of records of relics and the gathering of famous traditions by the culture of experts who submitted direct writing and not a few who gave it orally.

If we look further, can it be proven that the codified Hadith is truly free from political interference? Seeing the closeness of Abu Hurairah and Abu Darda to the Umayyad dynasty, it 
was even said that the association sold, the hadith for the Umayyad dynasty, averaged one dinar per hadith. Maybe some people take this hadith to discuss politics and think it right about the Messenger of Allah, arguing that the person who is speaking is also famous, memorized strong, and fair in his behavior. This is a critique returning to the science of rijalul hadith, which only addresses aspects of justice and rehabilitation of the narrator which is limited to being told or not, not in accordance with the narrator's background and according to what needs, which he uses a compilation of narrating the hadith.[26]

\subsection{Hadith "Hubb al-Arab Îmân" as The Hadith of Politicization}

There is a hadith that says: "that a leader must come from the Quraysh group". This violates the very nature of humanity established by the Prophet. And it has been clearly stated in the Qur'an that humans are all the same: only the level of piety distinguishes it.[27]

Likewise in the context of the hadith that I examined, namely the hadith about the obligation to love Arabic, while those who hate it are considered infidels. This hadith also reaps an ambiguous understanding if it is understood textually without regard to the analysis of the authenticity of the hadith and what is behind this narration of the hadith. Because as if only Arabs who get the glory while other nations do not. In this discussion, I identified that there was Shi'a intervention in the spread of this hadith, or politicians from the Arab universe in the second century to fight over the authority of leadership and glory in the social field at that time. This is proven by the fact that there are two rites considered "Shi'ah" in this hadith, namely 'Adi ibn Thabit Al-Kufi (116 H) and 'Ubaydullah ibn Musa Al-'Abasi Al-Kuf (213 H), both are equally life in the second-century hijriyah. Not only that, political and theological conflicts were also rife in that century, it was used by those who happened to be of Arab ethnicity to convince the Muslim community at that time to choose leaders from among the Arabs themselves.

\section{The phenomenon of Arab love in Indonesia}

\subsection{The Historical Context}

The Historical relationship between Arabs and Indonesians. There is no doubt that Indonesia is the country with the largest number of Muslims in the world. It has more than 17,000 islands and has a population of 250 million people consisting of 300 ethnic groups who speak more than 250 different languages. It is the largest archipelago, the fourth largest country and the largest Muslim population in the world. As the country with the most Muslims in the world, the role of Arabs is to spread the call of Islam in it. Arab-Indonesian relations have been established for a long time. Western history researchers say that Arabs arrived in Indonesia before Islam came. While Islam brought it, relations between Arabs and Indonesians continued, culminating in the days of the Bani Abbas Kingdom in Mesopotamia in the eighth to thirteenth centuries. After the fall of the Bani Abbas, the replacement of relations between Indonesia and Egypt, and the Portuguese state of emergency in the sixteenth century Indonesia.[28]

This is a close relationship between Arabs and Indonesians until the emergence of many Kingdoms in the role of Arabs, this is important for the spread of Islam in Indonesia, especially on Java.[29]

Among the Arabs who spread to the call of Islam were "wali songo" (wali sanga), and Arab traders and Habiba or so-called descendants of the Prophet Muhammad, peace be upon him, who came from Hadrami. And their important role in spreading Islam is those who are respected by Indonesians, and their great love, even to this day.[30] 
Today, the culture of Arab love still falls into the Islamic community in Indonesia. Seen in this case, many bags get special care. Most of them have built education councils in various regions in Indonesia. If they are different in taking the doctrine, but they are in the same destination is the call of Islam.[31]

\subsection{Understanding of "Arab Love"}

But at this time, with the trend returning to sunnah which is oriented towards understanding too textualist so that the attitude of takfiri becomes a polemic for Indonesian Muslims. The attitude of the people of this takfiri school is that it is easy to regard someone as a disbeliever and his actions that are not relevant to their opinions. This is a problem because most of the reasons they are easy to disbelieve others are because they do not use Arabic attributes, Arabic culture and something that is unique to Arabic. They consider that Arabic culture is Islamic culture and vice versa. They are so obsessed with Arabic that they cannot separate what is Islamic sharia from pure Arabic culture. In carrying out my research, I found more than one million articles with the keywords "hate Arabs", "anti-Arabs are infidels", hate Arabs hate the Prophet (s)". And the majority of the article discusses the hadith "hubb arab Faith wa bughdhuhum kufrun", then the hadith narrated for Salman al-Farisi "with takfiri understanding without explaining the hadith law in terms of both the quality of sanad and matan. Though it is clear that the hadith is a da'if that is problematic.

\subsection{Islam and Arabic Culture}

It can be said that there are still many Muslims and also non-Muslims still confused to distinguish between Islamic teachings (Islamic sharia) and Arabic culture or traditions. Ali Musafa Ya'qub, one of the hadith experts in Indonesia, he explained these two terms. According to him, religion and culture are two different things, but sometimes both can go hand in hand. Allah Most High revealed revelations on the Arab earth to a nobleman who was also an Arab. So do not be surprised if the source of Islamic teachings uses Arabic. Not only that, the growth and development of Islam are also inseparable from the culture prevailing there.

When Islam came to the archipelago, the Wali Songo used propaganda strategies that were appropriate and acceptable to the community, including cultural approaches such as puppets, dances, songs etc. As a result, the da'wah could be accepted so that Islam could spread throughout the archipelago, even Indonesia is now the first country with the largest Muslim population in the world. Isn't that a remarkable achievement? If only the saints of Songo were like that, then what about the method of preaching the Prophet who brought a new religion in the midst of the Quraish infidels? When was the Prophet released from all Arab cultures?

According to Ali Musafa Ya'qub, the criteria for religion and culture to be distinguished are: The teachings of Islam are practiced or practiced by Muslims only. In contrast to the culture of practice carried out by Muslims and non-Muslims. For example, the turban, before Islam came, the Arab community had used the turban. Muslims use the turban not because of orders from religion because at that time the infidels also used the turban. The difference is that Muslims are encouraged to use "qolansuwah" (cap) before wrapping it with a turban. This is so that the turban does not fall when they pray.

An Opinion that the turban is an Arabic culture is also strengthened by the fatwa of Saudi Arabia about the turban and also the fatwa of Fadhilah al-Shaykh Muhammad bin Shalih al-Utsaimin. So we can conclude that the turban is an Arabic culture, not a religious order so that it becomes sunnah. Even so, using a turban is still permissible. 
But apparently using a turban can be unlawful, that is for people who only use it alone and different from the surrounding community because it can be a shuhroh dress (popularity). Especially if the user aims to be easily known (popular) and grow in his heart a sense of arrogance.[32]

Arabs are ordinary people, they did not escape sin. As I mentioned earlier there are also beloved ones who have the criminal case even to the maximum. As a society in Indonesia, where we live on the island of Indonesia, we must obey the law and the law that they have decided upon them according to their mistakes, and do not tolerate them, as the Messenger of Allah peace be upon him said; "Whoever saw you are denied, he was able to change him in his hand, let him change his hand, if he could not His tongue, if he could not, with his heart, that weakened faith, The balance of differentiation and competition between people is piety and good deeds, as Almighty said:[33]

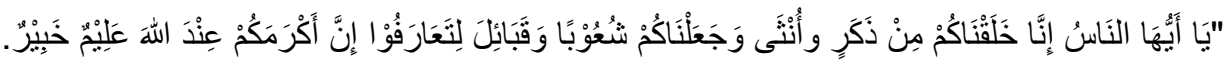

let us cultivate mutual respect between human beings regardless of race, social position, ethnicity, and others. Javanese need not feel more powerful; so do Chinese, or Germans. All nations have contributed, even the slightest, to the current world civilization. Respect for all; avoid the hatred of certain tribes or nations.

Let us reiterate the universal message of humanity conveyed by the Prophet Muhammad in his Wada sermon. This spirit of brotherhood on the basis of humanity will be the basis of world peace.

\section{Conclusions}

a. Hadiths "love the Arab faith and hatred" six sources. Five among them came from Anas bin Malik, and one source came from Adi bin Thabit. the mukharrij of the Anas bin Malik narrations are; al-Uqaili, al-Tabarani, al-Nisaburi, al-Bazar, and al-Isfahani. While "mukharrij" from Adi bin Thabit's narration is al-Baihaqi.

b. As for the quality of this hadith both in terms of sanad and matan, it is considered da'if because it is not in accordance with the norms and norms of criticism of sanad and matan. Even the level of $d a^{\prime} \hat{\imath} f$ is $d a^{\prime} \hat{\imath} f$ shadîd (very weak) so that there is no tolerance to practice it.

c. The Hadith that I studied is famous for the language of the scholars. Although the hadith is destined for weakness, the problem of "Arab love" in general is an interesting subject to pedal, especially for modern students. based on the fatwa of the ulema, that the correct explanation of this hadith is that we must not hate Arabs, because the Prophet (s) is an Arab, and my Arab friends and their role in Islam are innumerable, we must love Arabs and share this faith. Love is here in the sense of respecting them, and not saying damned words or hating them, especially to their offspring. But the Arabs are human and can make mistakes and sins. Therefore like ordinary people, we must remind them if they make mistakes, and give appreciation if they do good. And don't be too fanatical about loving them. the fact is that there is so much love for something that separates them from Allah SWT.

d. As for the intentions of non-believers in this hadith, it does not mean leaving Islam. This is as explained by Ibn Taimiyah. 
e. Judging from the contextual history of this hadith, which is the background why the narration of this hadith continues to spread even though its status is weak is because in the second year of Hijri there are many collections of hadith without the selection of the authenticity of the hadith. Therefore, this situation is used by certain elements for personal and political matters. To convince people at that time that they are people who have authority in social caste.

f. The phenomenon of Arab love in Indonesia is a tradition that is still practiced by the Islamic community in Indonesia since now. This shows the attitude of gratitude and respect to them (Arabic) for teaching religious knowledge and because of respect for the descendants of the Prophet. But because Indonesia is a pluralistic and cultural country, the context of love here does not reach the fanatical level. This is proven because of the entry into force of criminal law for Arabs who violate state rules. As the Indonesian community, where we live on the Indonesian island, we must obey the laws and laws that they have decided in accordance with their mistakes, and do not tolerate them.

g. But at this time, with the trend returning to sunnah which is oriented towards understanding too textualist so that the attitude of takfiri becomes a polemic for Indonesian Muslims. The attitude of the people of this takfiri school is that it is easy to regard someone as a disbeliever and his actions that are not relevant to their opinions. This is a problem because most of the reasons they are easy to disbelieve others are because they do not use Arabic attributes, Arabic culture and something that is unique to Arabic. They consider that Arabic culture is Islamic culture and vice versa.

h. All people are equal on the side of Allah, the only difference is their piety towards Him. This is like the Word of Allah Almighty:

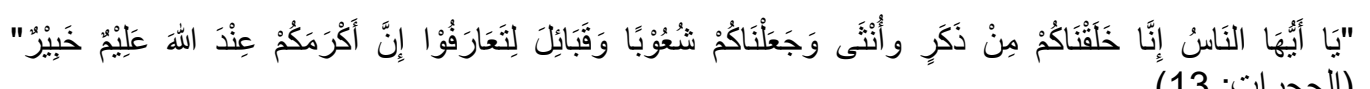$$
\text { (الحجرات: 13) (13) }
$$

Acknowledgements. This research supported by The Graduate School of Islamic Studies UIN Syarif Hidayatullah.

\section{References}

[1] Al-Hakim, “ Al-Mustadrak 'Ala al-Sahihain”, Lebanon: Dâr al-Ma'rifah, t.t.

[2] Al-Baihaqi, "Syu'ab al-Imân”, Riyadh: Maktabah al-Rusyd al-Nasirûn, 2003.

[3] Al-Tabrani "Al-Mu'jam Al-Kabîr”, Kairo: Maktabah Ibn Taimiyah, 1994.

[4] Al-Bazar, "al-Bahr al-Zakhar", Madinah: Maktabah al- 'Ulum wa al-Hikam, 2009.

[5] Al-Asfahani, "Hilyah al-'Auliyâ' wa al-Tabaqât al-Asfiyâ’”, Kairo: Dâr al-Fikr, 1996.

[6] Al-'Uqaili, “Al-dhu'afâ al-Kabîr”, Lebanon: Dâr al-Kutub al-'Ilmiyah, 1984.

[7] Al-Darami, "Al-Marjûhîn min Al-Muhaddîsîn wa Al-Ḍu'afầ wa Al-Matrûkîn”, Aleppo: Dar alWa'i, $1396 \mathrm{H}$.

[8] Mahmud Al-Thahan, "Taysîr al-Mustalah al-Hadîs", Alexandria: Markaz li al-Dirâsât, 1415 H.

[9] Ismail, M. Syuhudi, "Metodologi Penelitian Hadis Nabi”, Jakarta: PT. Bulan Bintang, 2007.

[10] Al-Hanbal, Ahmad bin, "Musnad al-Imam al-Ahmad bin al-Hanbal", al-Muassasah al-Risâlah, 2001.

[11] Al-Haitami, Ali bin Abu Bakr, "Majma' al-Zawaid wa al-Manba' al-Fawaid", Kairo: al-Maktabah al-Qudsi, 1994. 
[12] Al-Albani, Muhammad Nashiruddin, "al-Silsilah al-Ahadis al-Shahihah”, Riyad: al-Maktabah alMa'arif li al-Nasyr wa al-Tauzi', 1996.

[13] Al-Tirmidzi, "Sunan al-Tirmidzi", Kairo: Syirkah al-Maktabah wa al-Mathba'ah Mushtafa al-babi al-Halabi. 1975.

[14] Al-Tirmidzi, "Sunan al-Tirmidzi", Kairo: Syirkah al-Maktabah wa al-Mathba'ah Mushtafa al-babi al-Halabi. 1975.

[15] Hitti, Philip Kitti, "History of The Arabs, terj. R. Cecep Lukman Yasin dan Dedi Slamet Riyadi", Jakarta: Serambi Ilmu Semesta, 2014.

[16] Ahmad Khadafi, "Siapakah yang Dimaksud Orang Arab?", https://tirto.id/siapakah-yangdimaksud-orang-arab-cj3n. 2017.

[17] Azyumardi Azra, "Renaisans Islam Asia Tenggara - Sejarah wacana \& kekuasaan. Remaja Rosdakarya". (1999).

[18] Ibnu Taimiyah, "Iqtidha' al-Sirâth al-Mustaqîm li al-Mukhalafah”, Beirut: Dar al- 'Alam al-Kutub, 1999.

[19] Ibnu Taimiyah, "Iqtidha' al-Sirâth al-Mustaqîm li al-Mukhalafah”, Beirut: Dar al- 'Alam al-Kutub, 1999.

[20] Al-Dzahabi, "Târîkh al-Islâm wa al-Wafiyât al-Masyâhîr wa al-"A'lâm”, Dâr al-Garb al-Islâmî. 2003.

[21] Tim Ahlul Bait Indonesia (ABI), "Buku Putih Mazhab Syiah - Menurut Para Ulamanya yang Muktabar", Cetakan IV. ISBN: 978-602-8767-99-6. 2012.

[22] al-Zuhranî, Muhammad bin Matar, "al-Tadwîn al-Sunnah al-Nabawiyyah Nasy'atuhu wa Tatwiruhu min al-Qorn al-Tâsi' al-Hijrî”, Riyad: Dar al-Hijrah li al-Nasyr wa al-Tauzi', 1996.

[23] Al-Tabari, "Târîkh Al-Tabarî", Beirut: Dâr al-Turâth, 1968.

[24] Azami, Muhammad M, "Hadis Nabawi dan Sejarah Kodifikasinya", Jakarta: PT Pustaka Firdaus, 1994.

[25] Saifuddin, “Arus Tradisi Tadwin Hadis dan Historiografi Islam”, Yogyakarta: Pustaka Pelajar, 2011.

[26] Muhammad Zuhri, "Hadis Nabi Telaah Historis dan Metodologis", Yogyakarta: Tiara Wacana, 2011.

[27] Muhammad Zuhri, "Hadis Nabi Telaah Historis dan Metodologis", Yogyakarta: Tiara Wacana, 2011.

[28] Den Berg, L. W. C Ven, "Le Hadhralmaut Et Led Colonies Arabes Dans L' Archipel Indien", Jakarta: INIL, 1989.

[29] Hamid Algardi, "Islam dan Keturunan Arab dalam Pemberontakan Melawan Belanda", Bandung: Mizan, 1996.

[30] Antimateri.com. "Kaum Arab Hadrami di Indonesia: Sejarah dan Dinamika Diasporanya".Vol.2. 2017.

[31] Musa Kazhim, "Sekapur Sirih Sejarah "Alawiyin dan Perannya Dalam Dakwah Damai di Nusantara: Sebuah Kompilasi Bahan dalam Peran Dakwah Damai Habaib 'Alawiyin di Nusantara”, Yogyakarta: Rausyan Fikr Institute, 2013.

[32] Ali Mustafa Yaqub, "Cara Benar Memahami Hadis", Jakarta: Pustaka Firdaus, 2004

[33] Al-Tabrani, “Al-Mu’jam Al-Kabîr”, Kairo: Maktabah Ibn Taimiyah, 1994. 